\title{
Comparison of cytological 'jet-wash' specimens and histology in endometrial carcinoma
}

\author{
ELSA SEGADAL, OLE ERIK IVERSEN, AND MAGNAR ULSTEIN \\ From the Department of Obstetrics and Gynaecology, and the Department of Pathology, Haukeland \\ Hospital, University of Bergen, Norway
}

SUMMARY Jet-washing of the uterine cavity for cytological examination has been performed in 200 patients. The results were compared with the histological diagnoses obtained by curettage. In 24 patients with endometrial carcinoma, both methods showed one specimen to be 'not adequate' while the other showed malignancy. A combination of jet-wash and curettage gave a diagnosis in $96 \%$ of patients while curettage alone gave a diagnosis in $82 \%$, and cytology alone in $90 \%$. The method is simple and may be of special value in postmenopausal patients.

Cytological screening is established as the main method for detecting premalignant and malignant lesions of the cervix uteri at an asymptomatic stage. Several techniques for cell sampling from the endometrium have been reported, such as aspiration, brush biopsy, irrigation, and the Vabratechnique. Consistently good results have been reported with irrigation (jet-wash) introduced by Gravlee in $1969^{1}$ and the Curity sample aspiration technique of Isaacs and Wilhoite. ${ }^{2}$

There is a need for a screening procedure to detect endometrial premalignant and early malignant lesions as well as to screen high-risk groups, such as women receiving oestrogen substitution therapy. The aim of the present investigation was to compare the cytological diagnoses obtained with the Gravlee jet-washer with tissue diagnoses by curettage and, in particular, to assess the adequacy and representative nature of the specimen obtained by the washing technique.

\section{Patients and methods}

The patients in the study were 200 women referred to our clinic for diagnostic curettage (Table 1). Jet-wash was performed according to the technique described by Gravlee and was followed by curettage. It was done as a routine procedure by members of staff in the gynaecological department.

The material for cytological analysis was prepared by simply making smears after centrifugation. Smears were stained by the standard Papanicolaou method.

Received for publication 24 September 1979
Table 1 Indications for curettage

\begin{tabular}{lr}
\hline Indication & No. \\
\hline Postmenopausal bleeding & 124 \\
Meno-/metrorrhagia & 46 \\
Pelvic tumour & 7 \\
Myoma uteri & 5 \\
Cervical lesions & 14 \\
Others & 4 \\
Total & 200 \\
\hline
\end{tabular}

The cytological evaluation was done by one of us (ES). Clinical data were available but without knowledge of the results of the histological investigation. The histological examination was done as a routine procedure in the Department of Pathology. When reporting the diagnoses the following categories were used for both cytology and histology:

(1) carcinoma;

(2) adenomatous hyperplasia with mild, moderate, or severe atypia ;

(3) adenomatous hyperplasia;

(4) miscellaneous, including normal and atrophic endometrium.

Only specimens containing several sheets of cells and many single cells were accepted as representative and adequate for cytological investigation.

\section{Results}

Table 2 shows the adequacy of material obtained by the two methods. Enough material was found overall in $90 \%$ of the cytological specimens, and in $82 \%$ by curettage. In postmenopausal women the jet-wash technique gave adequate material in $87 \%$, and curettage produced satisfactory material in $75 \%$. 688 
In $3 \%$ neither method yielded sufficient material.

Table 3 shows the accuracy of the cytological method when compared to histology. Twenty-two cases of carcinoma detected cytologically were confirmed by histology. In one case jet-wash showed malignant cells while curettage did not produce adequate material. Later, hysterectomy showed adenomatous hyperplasia. Only two tissue blocks were available for study. The same case showed malignant adenocarcinoma cells, probably from the endometrium, in a routine cervical smear. In another patient a carcinoma was diagnosed by histology when the jet-wash technique failed to produce adequate material. As to the premalignant lesions, the cytological method has picked up all the cases with adenomatous hyperplasia with varying degrees of atypia. In three cases the cytological diagnosis was mild or moderate atypia when only adenomatous hyperplasia was reported histologically. Four cases with mild cytological atypia could not be evaluated as the histological material was not adequate; two cases of mild cytological atypia showed normal endometrium in the histological material.

\section{Discussion}

This study shows that a combination of jet-wash and curettage gives a diagnosis in $96 \%$ of patients, while curettage alone gives a diagnosis in $82 \%$, and cytology alone in $90 \%$. The jet-wash technique has given a higher rate of adequate material for study than curettage when applied to postmenopausal women. It is thus possible that lavage can compete with curettage in getting material from an atrophic endometrium. The jet-wash has been performed satisfactorily by all members of the clinical staff after a short introduction and the technique presents no problem to the clinician. Previous reports state that the method gives little or no discomfort to the patient. $^{3-6}$

This study reports a high accuracy for both malignant and premalignant lesions. Others have reported varying accuracy and regarded this as dependent mainly on the experience with this technique in the cytological laboratory. ${ }^{7}$ In this study the cytology was interpreted without previous training in this particular method. The cytological

Table 2 Adequacy of cytology and histology

\begin{tabular}{|c|c|c|c|c|c|c|}
\hline & \multicolumn{6}{|c|}{ No. of patients } \\
\hline & \multirow[t]{2}{*}{ Total } & \multicolumn{2}{|l|}{ Cytology } & \multicolumn{2}{|l|}{ Histology } & \multirow{2}{*}{$\begin{array}{l}\text { Histology and cytology } \\
\text { Inadequate }\end{array}$} \\
\hline & & Inadequate & Adequate & Inadequate & Adequate & \\
\hline $\begin{array}{l}\text { Premenopausal } \\
\text { Postmenopausal }\end{array}$ & $\begin{array}{r}63 \\
137\end{array}$ & $\begin{array}{r}2(3)^{*} \\
18(13)\end{array}$ & $\begin{array}{r}61(97) \\
119(88)\end{array}$ & $\begin{array}{c}1(2) \\
34(25)\end{array}$ & $\begin{array}{r}62(98) \\
103(75)\end{array}$ & $\begin{array}{l}0 \\
7 \text { (3) }\end{array}$ \\
\hline Total & 200 & $20(10)$ & $180(90)$ & $35(17)$ & $165(82)$ & $7(3)$ \\
\hline
\end{tabular}

*Percentages are shown in parentheses.

Table 3 Agreement between cytology and histology, giving the number of patients with the different diagnoses

\begin{tabular}{|c|c|c|c|c|c|c|c|}
\hline \multirow[t]{2}{*}{ Cytology } & \multicolumn{7}{|l|}{ Histology } \\
\hline & Carcinoma & $\begin{array}{l}\text { Atypical } \\
\text { hyperplasia with } \\
\text { severe atypia }\end{array}$ & $\begin{array}{l}\text { Atypical } \\
\text { hyperplasia with } \\
\text { moderate atypia }\end{array}$ & $\begin{array}{l}\text { Atypical } \\
\text { hyperplasia with } \\
\text { mild atypia }\end{array}$ & $\begin{array}{l}\text { Adenomatous } \\
\text { hyperplasia }\end{array}$ & Normal & $\begin{array}{l}\text { Inadequate } \\
\text { material }\end{array}$ \\
\hline Carcinoma & 22 & & & & & & 1 \\
\hline $\begin{array}{l}\text { Atypical } \\
\text { hyperplasia with } \\
\text { severe atypia }\end{array}$ & & 1 & & & & & \\
\hline $\begin{array}{l}\text { Atypical } \\
\text { hyperplasia with } \\
\text { moderate atypia }\end{array}$ & & & & & 1 & & \\
\hline $\begin{array}{l}\text { Atypical } \\
\text { hyperplasia with } \\
\text { mild atypia }\end{array}$ & & & 1 & 3 & 2 & 2 & 4 \\
\hline $\begin{array}{l}\text { Adenomatous } \\
\text { hyperplasia }\end{array}$ & & & & & 1 & & \\
\hline Normal & & & & & 1 & 118 & 23 \\
\hline $\begin{array}{l}\text { Inadequace } \\
\text { material }\end{array}$ & 1 & & & & 1 & 11 & 7 \\
\hline
\end{tabular}


results are good but interpretation was timeconsuming and difficult due mainly to the small numbers of cells and slight cellular differences between premalignant and malignant cell changes. The method may be technically improved by special filtration and cytospin techniques. ${ }^{8}$

These results do not justify the suggestion that jet-wash should replace curettage in postmenopausal bleeding. However, in patients without a definite indication for curettage, jet-wash can easily be done, and patients at risk can have an endometrial examination. Screening procedures may be undertaken as recommended in high-risk groups. ${ }^{9}$

This method can be performed on outpatients; it is easy to perform and is recommended especially for postmenopausal women. However, further studies are necessary to find the best method and to establish the clinical applications.

\section{References}

${ }^{1}$ Gravlee LC, Jr. Jet-irrigation method for the diagnosis of endometrial adenocarcinoma. Obstet Gynecol 1969; 34:168-73.

${ }^{2}$ Isaacs JH, Wilhoite RW. Aspiration cytology of the endometrium: office and hospital sampling procedures.
Am J Obstet Gynecol 1974;118:679-87.

3 Afonso JF. Value of the Gravlee Jet Washer in the diagnosis of endometrial cancer. Obstet Gynecol 1975;46:141-6.

4 Bibbo M, Rice AM, Wied GL, Zuspan FP. Comparative specificity and sensitivity of routine cytologic examinations and the Gravlee Jet Wash technic for diagnosis of endometrial changes. Obstet Gynecol 1974;43:253-6.

${ }^{5}$ Casey MJ, Madden TJ. Experience with endometrial irrigations in menopausal women. In: van Keep PA, Greenblatt RB, Albeaux-Fernet M, eds. Consensus on Menopause Research. Lancaster: MTP Press Limited, 1976:139-51.

- Henderson SR, Roxburgh DR, Bobrow LG, Pollard SM, Greening SE. Endometrial washings. Histological and cytological assessment of material obtained with an intrauterin Jet Washing device. Br J Obstet Gynecol $1975 ; 82: 976-86$.

${ }^{7}$ Hofmeister FJ. Endometrial biopsi: another look. Am J Obstet Gynecol 1974;118:773-7.

8 Vuopala S. Diagnostic accuracy and clinical applicability of cytological and histological methods for investigating endometrial carcinoma. Acta Obstet Gynecol Scand 1977; Supplement 70.

- Antunes CMF, Stolley PD, Rosenhein NB, et al. Endometrial cancer and estrogen use. $N$ Engl J Med 1979; $300: 9-13$

Requests for reprints to: Dr E Segadal, Department of Pathology, Haukeland Hospital, University of Bergen, Norway. 